\title{
Inclusive Development in Health Sector A Case in Surakarta City
}

\author{
Syarfina Mahya Nadila \\ Research Center for Society and Culture \\ Indonesian Institute of Sciences \\ Jakarta, Indonesia \\ mahya.nadila@gmail.com \\ Henny Warsilah \\ Research Center for Society and Culture \\ Indonesian Institute of Sciences \\ Jakarta, Indonesia \\ hennywarsilah@gmail.com
}

\begin{abstract}
Everyone guaranteed their rights in law. It includes the right to access health services for the rich and the poor. However, in reality, health services are difficult to access for the poor. The main causes are high cost, limited health workers, limited infrastructure, and lack of adequate hospital services. This writing is based on research about inclusive development in the health sector, particularly for the poor in Surakarta (Solo) City in Central Java Indonesia. The purpose of this research is to understand the implementation of health policy, which provides easy access for the poor to health services as a form of inclusivity in the development of Solo city. This research used the qualitative approach with in-depth interview data collection technique. One of the findings of the research is the Public Health Care Program (PHCP) in Solo as one policy enacted by the Municipal Government gives better access for the poor by providing a responsive and affordable health services. This policy can be successful because the Surakarta governments political will to make better health services. However, this policy cannot cover all the poor in Solo city. Challenges include the complicated procedures that limit health service's accessibility to the remaining poor in Solo.
\end{abstract}

Keywords - Social inclusion, health policy, access, health services, poor

\section{INTRODUCTION}

Everyone guaranteed their rights in law. It includes the right to access health services for the rich and the poor. This is as stated in the 1945 Constitution of the Republic of Indonesia Article 28H section (1), "Every person shall have the right to live in physical and spiritual prosperity, to have a home and to enjoy a good and healthy environment, and shall have the right to obtain medical care." However, in reality, health services are difficult to access for the poor. The privatization of healthcare industry makes health services too expensive and un-affordable for the community. In Indonesia, privatization usually interpreted as an activity to divert some government tasks to the private sector. In other words, the government diverts some their responsibility to provide basic services to the privates including health sector [1].
In principal, the privatization of healthcare facilities and services has shifted the health provider to gain benefit than serving the communities [2]. In the private health care facilities, they provide professional health workers and the best facilities to serve patients. This is compensation for the highest price. It causes only rich people can access this facility. Privatization of public hospitals will make it difficult for people to reach health services and even contrary to the mandated objectives provided in the 1945 Constitution [2]. As an impact, the people who live in under poverty line become excluded. The factors that affect the privatization of health care are the removal of subsidies for government hospitals and the privatization policy of health services that do not comply with the constitution [3].

The purpose of this research is to understand the implementation of health policy, which provides easy access for the poor to health services as a form of inclusivity in the development of Surakarta city.

\section{METHOD}

This research used the qualitative approach with indepth interview data collection technique. The characteristics of the informants are poor people and have Public Health Care Programs. In this research, there are two informants because of the limited time in the field. This research was conducted in seven days. The location of this research project was in Semanggi village, Pasar Kliwon Sub-District, Surakarta City, Central Java, Indonesia.

\section{RESULTS AND DISCUSSION}

In 2008, the municipal government of Surakarta issued one of the health program, which is called Public Health Care Program (PHCP). This program aims to provide protection and health services for the people in Surakarta City. For this program, the municipal government of Surakarta distributes two types of cards to their people. The cards were called Gold card and Silver card. The difference is, citizens who hold the Gold card can access health 
services for free, while the citizens who hold the silver card, have limited access to health services. They have to pay for health facilities if they exceed the limit. The Gold card holders only intended for poor people, but the Silver card is available for all people in Surakarta city.

This research's data came from two informants. The first was poor people in Semanggi village, Pasar Kliwon subdistrict, Surakarta City. They were initially was Public Health Insurance (Jaminan Kesehatan Social) card holder, but now she is the Gold card holder. Public Health Insurance is a health insurance program from the central Government funded by the state budget. Whereas, PHCP cards is a health insurance from Surakarta's City Government funded by Sukarta's regional budget. She said that although she can obtain the treatments for free with Gold card, it is limited to treatments in public hospitals. If she does the treatments in private hospital, she still has to pay. It was different when she used a PHI card. She still gets free access though she did the treatments in private hospital.

The second informant was also the Gold card holder. She acquired benefits of the Gold card when she delivered her first child through a cesarean section. She did not pay for that health service. She also told about the process to obtain a Gold card. It required approximately ten days. It was different with a Silver card which finished on the same day. She had to have Silver card before she requested the Gold card. She had to go through a bureaucracy of local municipal government from the neighborhood $(R T / R W)$, urban village (Kelurahan), sub-district (Kecamatan) and the last to Surakarta's Government. After she applied to municipal government, her house was surveyed by municipal health's officer of Surakarta city.

According to this informant, the Gold card expires in one year. She has to reapply for next years with the same schema. She said that it was inconvenient because the long process and it cannot be represented except by wife or husband. She also explained the stages when she delivered her baby. First, she did the check-up in community health clinic. After that, the doctor gave referral letter to public hospitals. All healthcare processes must pass through the community health clinic. If the conditions were getting worse, it would be referred to public hospital.

Further, she complaints on the limited number of hospitals that can serve freely for Gold card holder and the length of procedures to be followed regarding obtaining and extending the Gold card.

Social inclusion is used as an approach to build and to develop an increasingly open environment; invite everyone to come in with the different background, characteristics, abilities, status, conditions, ethnicity, culture and so on. Living in an inclusive circumstance means that everyone who lives and engages in a family, school or community environment feels secure and comfortable. Social inclusion can improve the life quality of the majority who have been excluded in many areas [4]. If there is no social inclusion, there will be social exclusion as argued by Gore et al. "Social exclusion can be seen as incomplete citizenship." [4]. Also, social inclusion prevents conflict so that people become more productive and competitive [4]. Thus, the inclusive environment is the environment which is open, friendly, fun, neglecting obstacles because people embrace every difference and respect each other [5].

There are three dimensions of social inclusion. Those are accessibility, participation, and freedom. Accessibility dimensions include resource and development. Participation dimensions include development and policies. Last but not least, freedom dimensions include participation and togetherness, network and institutional.

Besides in transportation, housing and education, inclusion in a public service such as in the health sector are often seen as an effort to fulfill citizens' rights in a welfare state. The public service is intended for the majority or lower layers, but this service is open also to the middle and upper layer [6].

The inclusive development aims to reduce poverty, inequality, and discrimination (similar to a nondiscriminatory fairness development model). Inclusive development can be realized if all stakeholders contribute to creating equal opportunities. The goal of inclusive development is to share the benefits of development outcomes and provide the widest possible space for participation in decision-making. The whole development process is based on respect for human rights, participatory, non-discriminatory and accountable values and principles. The inclusive development model can be used to create a society without discrimination. The main strategies of inclusive development are: (1) the creation of a productive and profitable employment, (2) the allocation of an effective and efficient social safety need to protect people who are unable to work or people who gain less development benefits, and (3) the improvement of basic public services, including services in health and adequate public policy support.

The municipal government-level health insurance program is designed to accommodate the health security needs that are not reachable by health insurance from the central government (Jaminas Kesehatan Nasional). The health security program of the central government only provides affordable health access for the poor. Supposedly, people of Indonesia are entitled to get health care insurance. Also, the national health program can not reach all the poor. Therefore, a local health service program is established.

In the case of Surakarta, the poor people, who were initially excluded, can access health services through affordable and easy health services by the municipal government of Surakarta. They make public health care program not just for poor people but also for all Surakarta citizen. This program successfully eliminates barriers to health services. Poor people can participate in access to health services. Poor people are also free from the burden of 
health costs. However, in some cases, there are still obstacles and challenges to be answered by the city government of Surakarta such as the complicated procedures that limit the health service's accessibility to the remaining poor in Solo.

\section{CONCLUSION}

Although there are so many weaknesses, this policy can be successful because the Surakarta governments political will to make better health services. This policy will bring change to the development of inclusive society in Surakarta City. It is expected that such a policy can be followed by other cities or regencies throughout Indonesia. Thus, inclusive development can be realized in Indonesia.

\section{References}

[1] Dumilah Ayuningtyas, "Politik Pembangunan dan Kebijakan Privatisasi Pelayanan Kesehatan", Jurnal Manajeman Pelayanan Kesehatan, Vol. 3, pp. 117, 2009

[2] Kementerian Kesehatan Republik Indonesia. Menkes Minta Privatisasi Rumah Sakit di Tinjau Ulang. 2015. http://www.depkes.go.id/development/site/jkn/index.php?vie $\underline{\mathrm{w}}=$ print\&cid $=717 \& \mathrm{id}=$ menkes-minta-privatisasi-rumahsakit-ditinjau-ulang accessed 28 August 2017

[3] Rizka Diputra. Diskriminasi Kesehatan Langgar Hal Asasi Rakyat. 2011. https://news.okezone.com/read/2011/03/15/338/435095/diskr iminasi-kesehatan-langgar-hak-asasi-rakyat accessed 28 August 2017

[4] Iwan Gardono Sujatmiko, "Privatisasi, Kapitalisme dan Negara Dalam Pelayanan Kesehatan (Suatu Studi Perubahan Sosial Dalam Industri Kesehatan)", Jurnal Masyarakat \& Budaya, Special Edition, pp. 57-74, 2010

[5] Rene Lenoir, Lex Exlus: Un Francais Sur Dix, Paris: Seuil Publication 1974.

[6] Iwan Gardono Sujatmiko, "Privatisasi, Kapitalisme dan Negara Dalam Pelayanan Kesehatan (Suatu Studi Perubahan Sosial Dalam Industri Kesehatan)", Jurnal Masyarakat \& Budaya, Special Edition, pp. 57-74, 2010 